\title{
ALLERGIC PROCTOCOLITIS IN INFANTS: analysis of the evolution of the nutritional status
}

\author{
Ludmilla S CAMARGO ${ }^{1}$, Jonas AC SILVEIRA ${ }^{1,2}$, José AAC TADDEI ${ }^{1}$ and \\ Ulysses FAGUNDES NETO
}

\begin{abstract}
Background - Allergic proctocolitis is a disease that affects infants in the first months. The change in feed is the primary factor for clinical improvement and maintenance of the nutritional status of the infant. Objective - Study the anthropometric evolution of infants with allergic proctocolitis at diagnosis and 1 to 6 months after nutritional intervention. Methods - A retrospective cohort of infants with allergic proctocolitis diagnosis followed at the Pediatric Gastroenterology Institute of São Paulo (IGASTROPED), Brazil. The database with clinical, therapeutic and anthropometric data was obtained from medical records of outpatient infants. The therapeutic intervention was characterized by 1) exclusive breastfeeding with maternal exclusion diet of the six allergens (EBF-MED) or 2) no breastfeeding and use of hypoallergenic formulas. Results - Of the 44 infants diagnosed with allergic proctocolitis, 23 were female. The median age of the infants was 3.5 months at the time of admission and 6 months after the intervention. The main clinical complaint was hematochezia with or without other symptoms of allergic proctocolitis. No difference was shown in the infants anthropometric evaluation between the two diets. Conclusion - The duration of the allergic proctocolitis did not induce worsening of the infants nutritional status. Importantly, both nutritional interventions were able to keep the infants within the growth channel and resulted in the total clinical symptoms remission. Considering the fundamental mother-child link promoted by breastfeeding, the present data highlights the beneficial role of EBF-MED on the nutritional status of infants diagnosed with allergic proctocolitis in addition to the lower cost that breastfeeding brings compared the use of hypoallergenic formulas.

HEADINGS - Colites. Breast feeding. Milk hypersensitivity. Infant nutrition.
\end{abstract}

\section{INTRODUCTION}

Food allergy (FA) is an adverse reaction to food involving the immune system that may be characterized as IgE mediated, IgE non-mediated or the mixed form $^{(1,5)}$. The actual prevalence of FA is poorly known and any kind of food protein can trigger an allergic reaction. However, most of the food allergy cases is caused by a food group and about $90 \%$ of the following food allergens are recognized: cow milk, egg, wheat, soy, corn, peanut, fish, seafood and almonds ${ }^{(13)}$.

Allergy to cow milk protein (CMPA) occurs on a larger scale and affects about $2 \%$ to $7 \%$ of infants in the first months of life, in this group age, the immune system is not fully developed yet to trigger inflammatory responses ${ }^{(11)}$. Although cow milk is usually included in the diet of infants to replace breastfeeding, it is the main allergen directly connected to $\mathrm{FA}^{(2,6)}$.

Allergic proctocolitis (AP) is a type of food allergy in a group of food hypersensitivities IgE non-mediated, also called eosinophilic proctocolitis. The AP pathophysiological mechanism has not been fully identified, but it is known to involve the presence of CD8 and TH-2 type cells and eosinophil infiltration in all mucosal layers. Moreover, the presence of current memory cells revealed by testing positive lymphocyte transformation suggests the involvement of T cells in the pathogenesis of AP, associated with the secretion of alpha tumor necrosis factor by activated lymphocytes. Evidences suggest that genetic factors exert important role in the expression of FA, since a high incidence of atopy history in the families of children with allergy proctocolitis have been described ${ }^{(8)}$.

AP commonly affects infants in the first months of life. It is a transitory disease, which in most cases disappears around the first year of life. The primary cause is the cow milk protein and/or soybean associated with breastfeeding, as we know that the mother's diet influences breastfeeding infants.

The clinical manifestations are recurrent and the main complaints are diarrhea, blood in the stool (hematochezia), cramps, intense irritability and difficulty in breastfeeding ${ }^{(7)}$. Considering that, the clinical manifestations of AP can result in a potential nutritional aggravation factor, and there is scarce association available in current literature ${ }^{(12)}$. The present study aimed to analyze the anthropometric evolution of infants with allergic proctocolitis (AP) at diagnosis and 1 to 6 months of nutritional intervention with monthly evaluation intervals. 


\section{METHODS}

From January 2010 to December 2013, 44 infants younger than nine months old, of both genders (21 boys and 23 girls) and living in different areas of São Paulo were attended consecutively and prospectively at the private office of the Pediatric Gastroenterology Institute of São Paulo (IGASTROPED) with a confirmed diagnosis of allergic proctocolitis. All the appointments were conducted by the same practitioner (Fagundes-Neto U).

\section{Diagnostic criteria}

All patients presented hematochezia (bright red blood mixed with the stool) associated with other symptoms such as diarrhea, irritability, cramps and food refusal at the first appointment. They were submitted to the following tests: blood count, stool culture for research pathogens, retoscopia or colonoscopy and rectal biopsy.

Morphological assessment of the rectal mucosa was performed according to the standard of Diaz et al. ${ }^{(7)}$, namely: Alteration of the surface epithelium, abnormal glandular architecture, mucous content infiltrating the lamina propria, lymphoid nodules, presence of granulomas, parasites, fungi, cytomegalovirus inclusion bodies and other viral inclusions.

The diagnosis of allergic proctocolitis was confirmed using the standard of Fiocchi et al. ${ }^{(9)}$, namely: Presence of rectal bleeding; exclusion of infectious causes of colitis; symptoms disappear after exclusion of milk and dairy products from the diet of the mother and/or child.

\section{Anthropometric measurements}

Body weight and length were assessed at the time of diagnosis and 6 months of nutritional intervention with monthly intervals of evaluation. Weight $(\mathrm{kg})$ was determined using an electronic scale and length was measured using a wooden stadiometer. For the assessment of nutritional status, all the analyses were performed based on the z-score weight for age, height for age, weight for height and body mass index (BMI) with the aid of Anthro program version 3.2.2 (2011) $)^{(15)}$, for children up to 5 years old and classified according to the World Health Organization (WHO) ${ }^{(3)}$ for each respective index.

\section{Nutritional intervention}

1) Patients in exclusive breastfeeding (EBF): the mother was submitted to exclusion diet (MED) of the six major internationally recognized allergens, namely: cow milk and dairy products, soy, fish and seafood, egg, and wheat derivatives and dried fruits (peanuts, walnuts, almonds, cashews, cocoa and hazelnuts), throughout the intervention period.

2) Patients on artificial feeding: exclusive use of hypoallergenic formulas (HF), such as extensively hydrolysed proteins formulas (HF-EHP) or basic amino acid mixture (HF-BAA).

\section{Statistical analysis}

In the descriptive analysis of the categorical variables they were presented as absolute numbers and frequencies, while continuous variables were presented as median and inter- quartile range (IQR). Inferential analyzes were conducted as outcome variable considering the difference among the $z$-scores of the anthropometric indices between admission and after the intervention. However, since the data of these variables were not normally distributed by the Shapiro-Wilk adhesion test $(P<0.05)$, the Wilcoxon test was used to test the hypothesis that the median $\mathrm{z}$-scores anthropometric indices in both periods were different from zero. The critical $P$ value used to disprove the null hypothesis was $5 \%$.

Additionally, we tested the difference of these same variables in relation to the type of diet (EBF-MED vs. HF- EHP or BAA) using the Mann-Whitney test.

All analyzes were conducted using Stata / IC 12.0 (Stata Corp LP, College Station, TX, USA) ${ }^{(14)}$.

\section{Ethical aspects}

The study was approved by the Ethics and Research Board of the Federal University of São Paulo-UNIFESP / Hospital São Paulo, (n $\left.{ }^{\circ} 749894\right)$. In the study, copies of the Consent and Informed (IC) were given to the legal guardian of all patients included in the study.

\section{RESULTS}

\section{Clinical characteristics}

Table 1 shows the general characteristics of the studied group. Of the 44 patients, $23(52 \%)$ were female.

TABLE 1. Clinical and nutritional characteristics of the patients

\begin{tabular}{|c|c|c|}
\hline & Admission $\% * \mathrm{~b}$ & Intervention $\% * c$ \\
\hline Sex (female) & $23(52 \%)$ & $23(52 \%)$ \\
\hline \multicolumn{3}{|l|}{ Birth weight } \\
\hline$<2.500 \mathrm{~g}$ & $4(11 \%)$ & - \\
\hline $2.500 \leq 3.000 \mathrm{~g}$ & $11(31 \%)$ & - \\
\hline$>3.000 \mathrm{~g}$ & $21(58 \%)$ & - \\
\hline \multicolumn{3}{|l|}{ Clinical manifestation } \\
\hline Hematochezia (exclusive) & $13(29,5 \%)$ & - \\
\hline Hematochezia with other symtoms** & $31(70,5 \%)$ & - \\
\hline \multicolumn{3}{|l|}{ Diet $^{\mathrm{b}, \mathrm{c} * * *}$} \\
\hline Breastfeeding $^{b} /$ EBF-MED $^{c}$ & $32(73 \%)$ & $17(39 \%)$ \\
\hline $\mathrm{PHF}^{b} . / \mathrm{HF}-\mathrm{EHP}^{\mathrm{c}}$ & $7(16 \%)$ & $24(54 \%)$ \\
\hline $\mathrm{MF}^{\mathrm{b}} / \mathrm{HF}-\mathrm{BAA}^{\mathrm{c}}$ & $5(11 \%)$ & $3(7 \%)$ \\
\hline \multicolumn{3}{|l|}{ Nutritional status (Z BMI/A****) } \\
\hline Thinner & $1(2 \%)$ & $2(5 \%)$ \\
\hline Eutrophic & $43(98 \%)$ & $41(93 \%)$ \\
\hline Overweight & - & $1(2 \%)$ \\
\hline \multicolumn{3}{|c|}{$\begin{array}{l}\mathrm{N}=44 . * \text { Absolute and relative frequency (categorical variables). } 36 \text { patients ( } 8 \text { without the } \\
\text { reported data)** Diarrhea, irritability, severe cramping, regurgitation. b: Diets at diagnosis } \\
\text { c: Prescribed diets (intervention); *** EBF-MED: exclusive breastfeeding with maternal diet } \\
\text { exclusion. PHF: partially hydrolyzed formula; HF-EHF: hypoallergenic extensively hydrolysed } \\
\text { formula; MF: milk formula. HF-BAA: hypoallergenic base amino acid formula } * * * * \text { z: score } \\
\text { body mass index for age. }\end{array}$} \\
\hline
\end{tabular}


The median age of the infants was 3,5 months in the admission and 6 months after intervention. The main clinical manifestation that led to the possible diagnosis of allergic proctocolitis was hematochezia (present in all patients), been unique and exclusive in $13(29.5 \%)$ infants and associated with other symptoms in $31(70.5 \%)$ infants. The most common symptoms associated with hematochezia were severe cramping, irritability, diarrhea, regurgitation, eczematous dermatitis and hard stools.

Analyzing feeding in the admission period $32(73 \%)$ infants were exclusively breastfeeding, 7 (16\%) were taking partially hydrolyzed formula (FPH) and $5(11 \%)$ were taking formula milk (FL). After the nutrition intervention, $39 \%$ of patients remained in EBF-MED feeding, $54 \%$ were taking extensively hydrolyzed proteins formulas (HF-EHP), 7\% use basis of amino acid mixture formula (HF-BAA) (Table 1).

Table 2 presents the analyzes that compared the infants nutritional status evaluated in two different moments (at the time of diagnosis and after dietary intervention). When analysis of pre and post intervention was performed, regarding the difference between the anthropometric parameters medians, it was observed that after the intervention infants gained weight and height in a statistically significant way, getting closer to the normal reference parameters defined by WHO for healthy children ${ }^{(3)}$.

It is important to say that the present results showed that no significant difference was observed in anthropometric parameters due to the type of nutritional treatment (EBF-MED and HP) $(\mathrm{P} / \mathrm{E} P=0.239)$ and the infants maintained satisfactory progress of their nutritional status. The mean of the positive response time to treatment was 3.3 (2.0 SD) months and from the first to the second query all patients presented remission of the symptoms.

\section{DISCUSSION}

The present research showed that in the assessment of the anthropometric evolution of infants with AP at different times (admission and after intervention) there was no difference between boys and girls diagnosed with AP, the main complaint was rectal bleeding and there was no weight loss report. These observations are consistent with those described by Lozinsky and Morais ${ }^{(10)}$, that in a review article show that patients often do not have weight loss or impairment of the general state or changes of palpation of the abdomen ${ }^{(10)}$. These observations point out the importance of nutritional monitoring of these children, since it is know that some manifestations that affect the gastrointestinal tract may implicate in the poor development of nutritional status of infants ${ }^{(4)}$. Aguiar et al., in a descriptive study at Rio Grande do Norte, Brazil, using similar methodology to the one employed in the present study, evaluated 214 children diagnosed with CMPA, referred to the Program of formulas for cow's milk allergy at in a Pediatric University hospital, the mean age was 3 months and they found that $49.5 \%$ of patients with clinical manifestations presented impairment of the digestive system simultaneously with other systems, such as respiratory and the skin. In the same study, they found $34.6 \%$ of patients with allergic colitis and the nutritional status analyzed by ZBMI showed thinness at $12.9 \%, 67.8 \%$ in normal weight, overweight risk in $15.2 \%$ and overweight at $4.1 \%$ (2). In accordance to the presented by the review study, we did not find statistically significant differences in relation to nutritional status before and after nutritional intervention when analyzing the parameters only.

Pereira et al. presented a data survey study that shows similar findings to ours involving 20 infants diagnosed with allergic proctocolitis that shows little impact on nutritional status and the infants look healthy, as result of the CMPA. In this study, $70 \%$ of the patients were eutrophic and $30 \%$ was malnourished, however, the nutritional parameters were measured using the Gomez criteria ${ }^{(11)}$.

TABLE 2. Anthropometric indicators of pediatric patients with allergic proctocolitis in pre- and post-intervention

\begin{tabular}{|c|c|c|c|c|c|c|c|}
\hline & \multicolumn{2}{|c|}{ Admission } & \multicolumn{2}{|c|}{ Pos-intervention } & \multicolumn{3}{|c|}{ Difference between the median } \\
\hline & Median & IIQ & Median & IIQ & Median & IIQ & $P$ \\
\hline Weight (kg) & 5.63 & $4.80 ; 6.98$ & 7.74 & $6.36 ; 8.96$ & 1.31 & $0.69 ; 2.60$ & - \\
\hline Height $(\mathrm{cm})$ & 60.75 & $55.5 ; 65.25$ & 68 & $63.5 ; 72.75$ & 5.75 & $3.5 ; 9.5$ & - \\
\hline Age & 3.5 & $2 ; 5$ & 6 & $4.5 ; 9$ & 3 & $2 ; 4$ & - \\
\hline $\mathrm{zW} / \mathrm{H}$ & -0.14 & $-0.5 ; 0.64$ & -0.04 & $-0.67 ; 0.79$ & 0.24 & $-0.40 ; 0.55$ & 0.38 \\
\hline $\mathrm{zH} / \mathrm{A}$ & -0.50 & $-1.43 ; 0.32$ & 0.025 & $-1.23 ; 0.55$ & 0.41 & $-0.33 ; 0.94$ & 0.01 \\
\hline
\end{tabular}

$\mathrm{N}=44$. IIQ: interquartile range; $\mathrm{zW} / \mathrm{A}: \mathrm{Z}$-scores for weight-for-age; $\mathrm{zW} / \mathrm{H}-\mathrm{Z}$ : score weight for height; $\mathrm{zH} / \mathrm{A}$ - Z: score height for age; $z \mathrm{BMI} / \mathrm{A}$ : Z-score body mass index for age. 
It is important to consider that studies which demonstrate the effects of nutritional therapy in the development of infants with AP has emphasized the use of hydrolyzed formulas, soy-based formulas and exclusion diets as forms of treatment $\mathrm{t}^{(2,11,16)}$. Yonamine et al. in a literature review, reports a study carried out with 168 infants with CMA evaluating nutritional status, which were assigned to two groups, namely: one received soy-based formula and the other received extensively hydrolysed formula. The evaluation of nutritional status was analyzed using laboratory test, weight and height data. The authors concluded that both treatments promote good evolution of nutritional status according to the Finnish reference standards, and that the choice of formula depends on the patient's tolerance and how much its cost. The retrospective observational study of a Spanish group, 141 infants with allergy cow's milk were analyzed using the z-score of weight and height, at birth, first appointment and one or two years older showed the same result when considering the form of treatment, noting that other food allergies such as eczema and wheezing appear frequently and can be negative for the nutritional status ${ }^{(16)}$.

According to the Academy of Breastfeeding Medicine ${ }^{(1)}$, allergic proctocolitis was one of the topics mentioned for creating the protocol for diseases that can compromise breastfeeding, suggesting not only to exclude cow milk, but the other allergens (soy, peanut, egg, corn, wheat, strawberry) from the maternal diet, but from the infants diets as well, so that the symptoms should disappear ${ }^{(10)}$.

In our research we compared the difference between the median of pre nutritional status parameters and post-intervention, we observed a statistically significant improvement compared to the z-score of H/A and W/A pointing the efficacies of both forms of treatment, exclusive breastfeeding with maternal exclusion diet and hypoallergenic formulas.

One limitation of this study is the sample size. However, allergic proctocolitis is not a highly prevalent disease and with no frequent diagnosis ${ }^{(17)}$, so the sample of 44 infants with a diagnosis of allergic proctocolitis is enough for clinical analysis and obtaining high value information.

\section{CONCLUSION}

Finally, we can conclude that allergic proctocolitis did not induce damage of the nutritional status of infants who receive proper nutrition intervention, if the diagnosis were performed early with effective forms of treatment, it will allow the infant to maintain the growth channel and promote the complete disappearance of the symptoms. Furthermore, it highlights the beneficial role of breastfeeding with maternal diet exclusion in the nutritional maintenance process of infants, a practice that has proved highly effective in the treatment of allergic proctocolitis. Thus, the incentive for mothers to perform the elimination diet and continue breastfeeding should be increased, providing not only a good nutritional status, but also strengthen the "bond mother and child" in such a particular situation such as allergic proctocolitis; in addition, the introduction of hypoallergenic formulas, may be expensive or unaffordable for many families.

\section{ACKNOWLEDGMENT}

The Federal University of São Paulo and the Pediatric Gastroenterology Institute of São Paulo (IGASTROPED) by all documents necessary for research. CAPES (Higher Education Personnel Improvement Coordination) granted the scholarship.

\section{Authors' contributions}

Camargo LS: participation in drafting the article and in the preparation and conduct of the research project. Silveira JAC: participation in data analysis and writing of the article. Taddei JAAC: participation in database oriented analysis and research. Fagundes Neto U: participation in the writing and co-directing research.

Camargo LS, Silveira JAC, Taddei JAAC, Fagundes Neto U. Proctocolite alérgica em lactentes: análise da evolução do estado nutricional. Arq Gastroenterol. 2016,53(4):262-6.

RESUMO - Contexto - Proctocolite alérgica é uma enfermidade que afeta lactentes nos primeiros meses. A modificação na alimentação é o fator primordial para melhora do quadro e manutenção do estado nutricional do lactente. Objetivo - Avaliar a evolução antropométrica de lactentes com proctocolite alérgica no momento do diagnóstico e 1 a 6 meses após a intervenção nutricional. Métodos - Coorte retrospectiva de lactentes com diagnóstico de proctocolite alérgica acompanhados no Instituto de Gastroenterologia Pediátrica de São Paulo (IGASTROPED), Brasil. Os dados foram obtidos a partir dos prontuários de lactentes atendidos ambulatorialmente, coletando-se informações acerca do diagnóstico clínico, conduta terapêutica e dados antropométricos. A intervenção terapêutica foi caracterizada 1) aleitamento materno exclusivo com dieta de exclusão materna de seis alérgenos (AME-DEM) 2) fórmulas hipoalergênicas. Resultados - Dos 44 lactentes diagnosticados com proctocolite alérgica, 23 eram do sexo feminino. A mediana de idade dos lactentes foi de 3,5 meses no momento da admissão e de 6 meses após a intervenção. A queixa clínica principal foi hematoquezia associada ou não a outros sintomas da proctocolite alérgica. Não houve diferença estatística na avaliação antropométrica dos lactentes em ambas as dietas. Conclusão - A vigência da proctocolite alérgica não provocou agravo do estado nutricional dos lactentes e apesar de diferentes intervenções nutricionais, os lactentes se mantiveram dentro do canal de crescimento e ocasionou o desaparecimento total dos sintomas clínicos. A despeito destes resultados, destaca-se o papel benéfico do AME-DEM no processo de manutenção do estado nutricional do lactente e do vínculo mãe e filho, além do menor custo que o aleitamento materno traz comparado a utilização de fórmulas hipoalergênicas.

DESCRITORES - Colite. Aleitamento materno. Hipersensibilidade a leite. Nutrição do lactente. 


\section{REFERENCES}

1. Academy of Breastfeeding Medicine. ABM Clinical Protocol\#24: Allergic Proctocolitis in the exclusively Breastfed infant. Breastfeeding Medicine. 2011;6:435-40.

2. Aguiar ALO, Maranhão CM, Spinelli LC, Figueiredo RM, Maia JMC, Gomes RC, et al. Avaliação clínica e evolutiva de crianças em programa de atendimento ao uso de fórmulas para alergia a proteína do leite de vaca. Rev. Paul. Pediatr. 2013;31:152-8.

3. Brasil. Ministério da Saúde. Política Nacional de Alimentação e Nutrição. Curvas de Crescimento da Organização Mundial de Saúde, OMS, 2006.

4. Castro APBM, Jacob CMA, Corradi GA, Abdalla D, Gonçalves RFF, Rocha FT, et al. Evolução clínica e laboratorial de crianças com alergia a leite de vaca e ingestão de bebidas à base de soja. Rev. Paul. Pediatr. 2005;23:27-34

5. Cianferoni A, Spergel JM. Food allergy: review classification and diagnosis. Alergol. Int. 2009;58:457-66.

6. Coco RR, Souza FS, Sarni RO, Mallozi MC, Solé D. O papel da nutrição no primeiro ano de vida sobre a prevenção de doenças alérgicas. Rev Bras Alerg Imunopatol. 2009;32:68-71.

7. Diaz NJ, Patrício FS, Fagundes-Neto U. Allergy colitis: clinical and morphological aspects in infants with rectal bleeding. Arq. Gastroenterol. 2002;39:260-7.

8. Fagundes-Neto U, Ganc AJ. Proctocolite alérgica a evolução de uma enfermidade de caráter transitório e de tendência familiar: Relato de caso. Einstein. 2013;11:229-33.

9. Fiocchi A, Brozek J, Schuneman H, Bahna SL, Von Berg A, Beyer K, et al. World Allergy Organization (WAO) Special Committee on food allergy. World Organization: diagnosis and rationale for action against cow's milk allergy guidelines. Pediatr. Allergy Immunol. 2010;21:1-125.
10. Lozinsky AC, Morais MB. Eosinophilic colits in infants. J Pediatr. (Rio J). 2014;90:16-21.

11. Pereira PB, Silva CP. Alergia a proteína do leite de vaca em crianças com repercussão da dieta de exclusão e dieta substitutiva sobre o estado nutricional. Pediatr. 2008;30:100-6.

12. Silva A F, Schieferdecker MEM, Rocco SC, Amarante HMBS Relação entre estado nutricional e atividade inflamatória em pacientes com doença inflamatória intestinal. Arq. Bras. Cirur. Diag. 2010; 23:154-8.

13. Solé D, Silva LR, Rosário Filho NA, Sarni ROS. Consenso Brasileiro sobre alergia alimentar 2007. Rev Bras Imunopatol. 2008;31:65-89.

14. STATA Data Analysis and Statistical Software, College Station, version 12.1, Texas, USA, 2011.

15. WHO. World Health Organization Anthro for personal computers [computer program]. Software for assessing growth and development of the world's children. Version 3.2.2 Geneva; 2011.

16. Yonamine GH, Castro APBM, Pastorino AC, Jacob CMA. Uso de fórmulas à base de soja na alergia a proteína do leite de vaca. Rev. Bras. Alerg. Imunopatol. 2011;34:187-92.

17. Yu M, Tsai C, Yang,Y,Yang S, Wang L, Lee C, et al. Allergic Colits in infants related to cow's milk clinical characteristics, pathologic, changes and immunologic findings. Pediatrics and Neonatoloy. 2013;54:49-55. 